\title{
Sustainable Business Strategic Model for Private Health Care Set Ups, Pakistan
} \section{Authors: Salman Sarwar ${ }^{1}$; M. S. Nadeem ${ }^{2}$; Mehar Nigar ${ }^{3}$; Talha Bin Saeed $^{4}$}

\author{
Institute of Management Sciences Lahore*University of Lahore ${ }^{2}$; Riphah Int. Unviersity ${ }^{3}$; Allied Hospital, \\ Fsbd $^{3}$
}

Salmansawar333@gmail.com; Shahid.etc12@gmail.com; m.nigar3@gmail.com; Talhaa.mt43@gmail.com

\section{DOI:10.26821/IJSRC.9.9.2021.9907}

\begin{abstract}
Health care setups are under intense pressure they have been never before, in particular private medical and health care setups are struggling to fight against pandemic of covid 19 and internal financial challenges. The objective of the study was to offer and design a sustainable business strategies model that can offer support to private medical and health care setups to sustain and survive this intense wave. Leaders are facing immense pressure to optimize resources for producing desired output and find efficient means to deliver in a highly competitive environment.In this study. Data was collected through simple random sampling. In this study 310 respondents participated in the survey who were senior executives in corporate private medical colleges, hospitals, clinics, and pharmacies in Lahore, Pakistan. The results were received at after conducting Multiple Regression Analysis. Results reveal that the sustainable business strategies research variable along with quality treatment of the ailing society, knowledge implementation, Human capital, and Transformational leadership and Financial management skills been predicted variables to define a model that will offer assistance to private medical and health care set ups. The findings also reveal that transformational leadership and financial management skills along with knowledge implementation that are considered essential for a sustainable business strategies for private health care set ups. The paper contributes to academics and industry practitioners by presenting findings that are exclusive to the sustainable business strategies for private health care setups. This study will facilitate the
\end{abstract}

formulation of strategies that are conducive in industries for the induction and training of the leadership.

Keywords: covid 19 situation, private health care setups, sustainable business strategies for private medical set ups, transformational leadership.

\section{Introduction}

One cannot think a world without health care services. That world will be of miseries and pains. Now, imagine a world with health care but of poor quality. That must be a world of greater miseries and greater pains. The payments for the health treatment brings agony if the health does not recover. Furthermore, it will be an obstacle of the prescribed healthcare services in terms of prevention, treatment and management (Cossette B. et al., 2016).

Implementation of knowledge into practical scenario is a vibrant and coordinative process that attaches production, dissemination, exchange and application of knowledge to enhance service delivery (Graham ID. et al., 2018).Hindrances in the way knowledge application attach shortage of or incompetency to reach knowledge resources, indifference towards the knowledge attained viaresearch outputs (Banja JD. et. Al., 2013). Shortage of time to get an empirical proves that can assist managers and policy makers (YousefiNooraie R. et al., 2009).In addition, managers usually make decisions on the basis of information achieved from recommended sources and results of routine organizational measurements rather than research findings (Rosenbaum SE.et.al., 2011). In recent decades, several models have been proposed 
on how to apply knowledge in practice or facilitate this process(Ward V. et.al. 2009) .

The "Promoting Action on Research Implementation in Health Services" (PARIHS) is a practical idea that was engineered by Kitson et al. (1998) with the aim to enhance research outputs in real time setting. This framework throws lights on the coordination of evidence, context and facilitation for successful implementation. These elements made up of some sub-elements, which define them. Evidence is defined by sub-elements of research findings, experiences of service providers and recipients as well as local information (i.e. Organizational knowledge); culture refers to the sub-elements of leadership and evaluation methods and the last element, facilitation, is defined by goals, roles and skills of individuals in/ out of the organization that helps others make things easier (Harvey G. et.al., 2015).

\subsection{Problem Statement}

Health care services set ups mostly struggle to manage their operations due to financial constraints. The society believes that health care services set ups offer treatment to the patients and they are not supposed to work on profitable models. The investors don't see sufficient scope for them to put money and work as business unit. This is marked gap that generally health care set ups suffer to proceed or shut down their private sector hospital most of the time.

\subsection{Significance of the Research}

The gap between information and practices of the health system actually create troubles in tertiary care set ups. Private sector health care management need to create balance between community service and producing profitable unit at the same time.

Academic literature and market surveys are bound with research pertaining to all the variables identified for this study. However, to the best of the researchers' knowledge, this research gap where health care service set ups design and plan business strategies that produce profits in the long run successful operations of the set ups of the other research variables are identified has hitherto not been done in Pakistan medical and health care context. To delve further into the research, a systematic review of literature on all the variables to this study has been conducted.

\subsection{Research Objective}

This research is aimed to achieve the objectives in defining business strategies for the health care set ups to perform in uncertain situation. The study will bring out the specific traits and skills of knowledge management and human capitals working under intense environment. Since year 2020 has proved to be the year of volatility, uncertainty, complexity, and ambiguity, so it becomes top urgent to learn new ways not only to cope the situation but also convert health care set ups as successful and profitable business units. This research will help to offer an idea of doing health care services with quality treatment and reasonable profits through effective business strategies.

\subsection{Research Questions}

The study is determined to find out a sustainable business strategies that enhance the profitability to power health care service set ups by added revenues and achieve the quality of treatment. The study will be conducted considering the knowledge implementation and human capitals as the most important variables to achieve the ultimate goal.

The research aims to establish empirical evidence for the measurement of health care set ups to perform up to patient's expectations along with profitable units. The following objectives are framed to achieve the overall goals:

1. Examine the knowledge implementation on the health care set ups and hospitals to sustain and survive under financial constraints.

2. Investigate the variables of Human Capitals as the most important to serve the community in crises and pains as well as surviving the financial crunch.

3. Draw implications of effective business strategies to sustain and grow in the long run for the health care set ups.

\subsection{Literature Review}

The health care sector is one of the most important sectors in a country as it influences other areas and has medical, social, political, moral, business, and financial implications and outcomes (Bahadori, M.et.al.2018).Absence of health nullifies the importance of everything, including every 
achievement. No wealth matters, if one is not healthy to fully benefit from it. Developed countries are not only continuously developing their health care sector but also generating revenues for their national economy by promoting health tourism(Javed SA. et.al. 2018).

On the other hand, the leaders and decision makers of developing countries like Pakistan instead of developing the health care in their own countries are helping the health care sector of developed countries by seeking their services frequently, usually at the expenses of taxes being paid by their own country mates(Javed SA. et.al. 2018). Thus, not developing a sector is a double- edged sword.

In Pakistan health care topics are more appreciated by scholars instead lawmakers, (Javed SA. et.al. 2018)this is not strange that less budgeted health care expenditures are $66.5 \%$; while the world's average is $18.147 \%$,(World Bank. 2018).

Why the reason when health care system is not supporting national cause to satisfy the need of cusomers (Shabbir A. et.al. 2016)and the logic the most of the Pakistani citizens understand that the corruption is prevailing in health care sector(Gadit AAM. et. al., 2011).Under these factual statement, one must study the performance criteria in poorly performing developing nations get more intention than that of their counterparts in the developed world because it is a matter of life and death for the peoples of these countries.

Javed SA. et.al. 2018noted that "despite this despondent situation of healthcare in Pakistan, where quality initiatives are relatively more visible in the manufacturing, education and agriculture sectors than in the healthcare sector, not many scientific studies have been done in this context." In the given context, in the current study, the perceived performance of public and private health care systems of Pakistan has been evaluated by gauging the satisfaction of Pakistani patients from the two sectors in light of their perception of the five- dimensional health care service quality construct (SERVQUAL). Also, the study intends to identify and rank key quality measures that influence patients' satisfaction in a given sector. The study is novel as it addresses the problem through novel grey systems theory- based models, which work well even for small sample size and systems with uncertainty.

\subsubsection{Health service quality}

Service quality has become an important issue since the service industries started competing traditional industries like manufacturing and production. Services presently represent more than two- thirds of world's gross domestic product(WTO. 2018). Initially, quality was an industrial concept, but now, its importance in service organizations is exceedingly getting noted. Today, quality is a fundamental determining factor in both industrial and service sectors to achieve maximum return on investments while minimizing costs(Irfan SM. et.al. 2011).These days, all organizations delivering services of one kind or another are looking for ways to improve the quality of services to produce more satisfied service consumers and thus making the organizations more profitable or productive.

In health care systems, quality of health care services is gaining exceeding focus being a technique for judging the performance of the health care system and accomplishing competitive advantage and patient loyalty(Bahadori, M.et.al., 2011). Quality is a relative term, and its definition depends on who is defining it and in what perspective. In its simplest form, quality is a comparison between expectations and performance(Parasuraman A.et.al., 1985). Quality can also be defined as "the quality of scope in the usage of product or service at certain level which meet the expected requirement."(Javed SA. et.al. 2018)defined perceived health care quality as "the patients' judgment or impression about a healthcare unit's overall excellence and superiority." At its core, there are two ways to define service quality: mechanistic (objective) and humanistic (subjective). In health care context, mechanistic quality implies an objective aspect or feature of the health care service while humanistic quality implies subjective response of patients to the health care service(Parasuraman A. et.al., 1988). There are also other ways to define service quality as can be found in (Purcarea et al., 2013).

\subsection{Research Model}




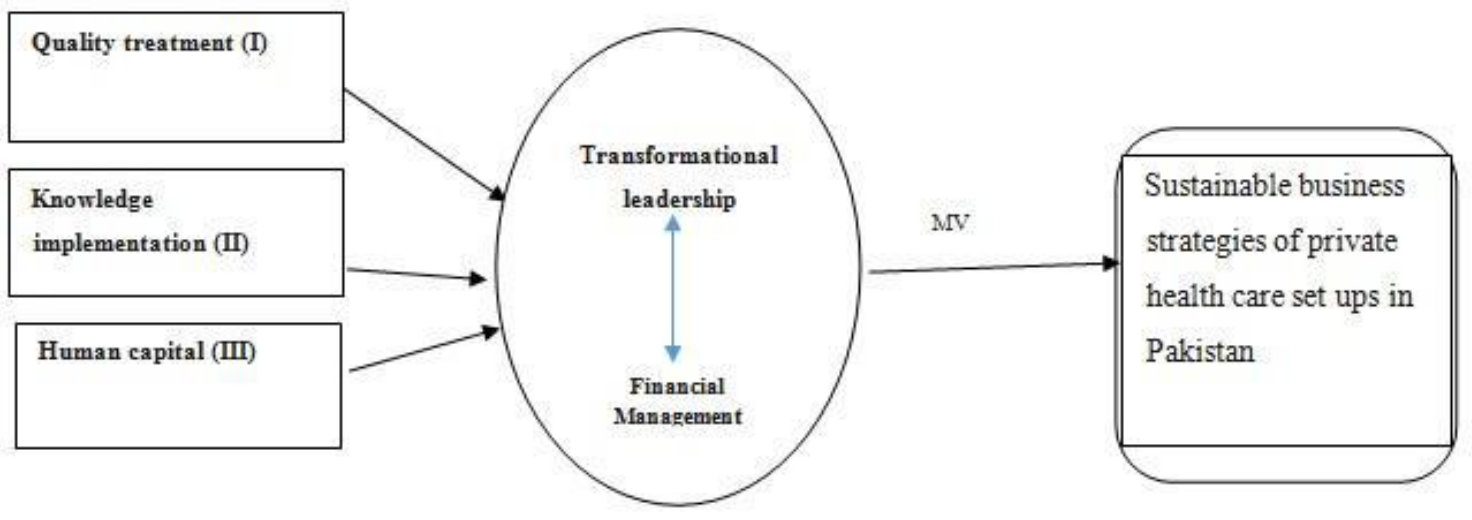

\section{Hypothesis}

- H1Quality treatment will have positive significant impact on sustainable business strategies in private health care set ups.

- H2Knowledge Implementation will have positive significant impact on sustainable business strategies in private health care set ups.

- H3 Human Capital management will have positive significant impact on sustainable business strategies in private health care set ups.

- H4Transformational Leadership and financial management will have positive significant impact on sustainable business strategies in private health care set ups.

\subsubsection{Quality Measurement}

Health care has been evolved into a highly competitive andemerging industry around the globe worldwide(Shafiq M. et.al. 2017).Upgrading quality of servicesenhances profit margins, market share, costs, customer retentions, and effectiveness of marketing campaigns (Rezaei J. wt.al., 2017).Thus, understanding the significance of service quality, defining, measuring, and managing it is pivotal for service organizations. Nonetheless, one of the "biggest challenges faced by healthcare markets is to define and measure the service quality (Irfan SM. et.al., 2011).

Health care service quality is an objective phenomenon, and its evaluation is not easy; but still, it can be measured through subjective means, as can be seen from wide array of studies involving patients' observations directed

\subsubsection{Knowledge Implementation}

Strong evidence shows the positive effect of sharing information on employee performance. The most common findings are that the use of integrated information and expert opinion agreed to share information improves efficiency in performance, problem solving and decisionmaking, leading to improved staff performance (Kang et al., 2008; Masa'deh et al., 2016; Reychav \& Weisberg, 2009; Zhu, 2016).

The basis of the concept of each learning strategy is that although clear information can be officially transmitted, the expansions of each learning require that certain information be transferred as well. As the transmission of confidential information, especially what is on the minds of experts, "cannot be documented and can only be seen through its use and can only be obtained by practice" (Grant, 2006, p. 111).

Strong evidence shows the positive effect of sharing information on employee performance. The most common findings are that the use of integrated information and expert opinion agreed to share information improves efficiency, problem solving and decision-making, leading to improved staff performance (Kang et al., 2008; Masa'deh et al., 2016; Reychav \& Weisberg, 2009; Zhu, 2016). However, the idea that information sharing improves performance is not universal. Previous research suggests that many aspects of the situation may influence the performance results of information sharing. For example, aggressive surveillance style and lack of management support can reduce the positive impact of information sharing on staff performance (Kim \& Yun, 2015; Ozer \& Vogel, 2015; Park et al. 2015). 
Implementing knowledge into practice is a dynamic and interactive process that includes production, dissemination, exchange and application of knowledge to improve service delivery(Pramanik A.et.al., 2016). Barriers to knowledge utilization include lack of or inability to access knowledge resources, indifference towards the knowledge gained through research findings(Patrick DL. et.al., 2000) and lack of time to find evidence that can help managers and policy makers(Taner T. et.al.,2006). Moreover, managers generally make decisions based on the information gained through recommendations and results of routine organizational measurements rather than research findings (Siddiqi S.et.al., 2010). In recent decades, several models have been proposed on how to apply knowledge in practice or facilitate this process (Ocampo L.et.al., 2017).

\subsubsection{Human Capital}

Organizations around the globe normally plan their strategies for human resource management, ideal policies, and business plans with their overall corporate strategy to share added value in the organizational efficiency and competitive advantages (Gurbuz \& Mert, 2011; Zehir, Gurol, Karaboga, \& Kole, 2016; Abdallah \&Alkhaldi, 2019). Becker also argued that ongoing education is an opportunity that must be continued to the point where the marginal productivity gains are balanced with the marginal opportunity costs (Solomon, 2019). The screening theory (Stiglitz (1975), which helps explain how employers notice differences in individual productivity as a way to provide individuals with productivity-based wages, also emerged.

Moreover, this theory suggests that at the beginning of work, all employees must be provided with the same remuneration. According to Kang (2015), adjusting performance incentives, largescale employee recruitment, team-based systems, job restructuring, and employee satisfaction and engagement lead to overall business efficiency improvement. Training and growth will promote employees' future career paths and related skills. As a training climate, the workplace is a catalyst and also produces positive organizational results through strategic implementation (Saks \& Burke; Smalley, 2014). The following hypothesis is thus suggested:

\subsubsection{Transformational leadership}

Leadership is a widely acknowledged area in the literature. Its impact on the organizational goal's achievements become more evident. Scholars, such as (Hater \& Bass, 1988; Den Hartog \& Belschak, 2012) presented in the literature as explaining the significant approach of transactional and transformational leaderships. Transactional leadership is defined as the exchange of rewards and objectives between employees and managers (Howell \& Avolio, 1993). Further, transactional leaders motivate employees with rewards to fulfill requirements (Bass, 1990; Humphreys, 2002; Tajeddini, 2016). Besides, transformational leadership focuses on the development of followers and their needs. Managers asserting transformational leadership approaches for the enhancement of value system of employees, mainly rewards and motivation along with morals (Ismail et al., 2012). Moreover, transformational leaders perform as a facilitator between leaders and followers to design transparent understanding of follower's interests, values and motivations (Bass, 1994; Bycio et al., 1995; Tajeddini et al., 2017).

\section{Research Methods 3.1 Research Design}

The study followed a multi-phase analysis style to screen the size that help defining effective business strategies for health care set ups in an exceedingly uncertain and volatile context. The study will be exploratory and empirical in nature. 'The ideas and models evolved because the analysis created progress each in terms of literature review and field work on business strategies for private health care set ups.

\subsection{Population}

The study will be conducted in medical and health care set ups. In this regard medical colleges and health care setups such as tertiary care hospitals will be population for this particular study. Population will be targeted in form of chairman, Directors, Principals, and Leaders in all department of medical colleges and hospitals.

\subsection{Sampling}

During this study, stratified random sampling will be used. Stratified sampling could be a sampling technique within which the population is split into teams known as strata. "The plan behind 
proportional sampling is that the groupings are created so that the population units inside within a group are similar." (Salkind, 2007). Since the criterion for inclusion within the study are the age, gender, qualification, and position bracket of the respondent, the researcher will use this sampling technique. The estimated sample size will be 300 .

\subsection{Analysis Techniques}

For measurement of the variables, a structured questionnaire with 5-point Likert scale will be used for collecting the quantitative data from the medical and health care professionals.

The Means, Standard Deviations, Pearson's Correlation and Discriminant Validity tests will be carried out. Multiple Regression Analysis will be used to predict the dependent variable (business strategies with profitability) using the independent variables (quality service treatment, knowledge implementation, human capital, and transformational leadership. The SPSS 25.0 software will be used for analysis of data.

\subsection{Expected Outcomes}

The study outcomes are aimed to produce a viable and workable business strategies that offer quality service of treatment along with profitability. The results can indicate favorable clues for the investment in this sector.

\subsection{Time line for the study}

The study will be conducted from March 2021 December 2021. The study is expected to generalize so far as the outcomes are concerned in coming decade that will be extremely volatile,

Uncertain, complex, and ambiguous in nature. The study will particularly offer medical and hospital leaders to face the dynamic situation.

\section{ANALYSIS AND RESULTS 4.1 DESCRIPTIVE STATISTICS}

The descriptive statistics of the dataset were initially examined. The study was conducted in

Lahore, Pakistan, considered the best city in the country so far as medical and health care facilities, professionals to serve are concerned that offer education and treatment to around nine million people. Male $61 \%$ while female $39 \%$ respondents in the study. The criterion for participation in the study was for all age groups. Experience criteria were from one year to more than 25 years while they had the designation of Director, Managers, Supervisors, Medical consultants etc. It is evident from the descriptive statistics that the respondents possess appropriate suitability to be part of the research study.

\section{Descriptive Statistics See table 4.}

\section{Statistics See table 1.}

\begin{tabular}{c|c|c|c|c}
$\begin{array}{c}\text { Gen } \\
\text { der }\end{array}$ & Age & gesi & Expe & Type \\
of & of & rienc & s of \\
on & e of & Heal \\
the & the & the & the & th \\
Resp & Resp & Resp & Resp & care \\
onde & onde & onde & onde & setup \\
nt & nt & nt & nts & s
\end{tabular}

\begin{tabular}{|c|c|c|c|c|c|c|}
\hline \multicolumn{3}{|c|}{$\mathrm{nt}$} & nt & $\mathrm{nt}$ & nts & $\mathrm{s}$ \\
\hline \multirow[t]{2}{*}{$\mathrm{N}$} & $\begin{array}{l}\text { Val } \\
\text { id }\end{array}$ & 310 & 310 & 310 & 310 & 310 \\
\hline & $\begin{array}{l}\text { Mi } \\
\text { ssi } \\
\text { ng }\end{array}$ & 0 & 0 & 0 & 0 & 0 \\
\hline \multicolumn{2}{|c|}{ Mean } & 1.53 & 2.80 & 2.75 & 2.75 & 2.80 \\
\hline \multicolumn{2}{|c|}{$\begin{array}{l}\text { Std. } \\
\text { Error of } \\
\text { Mean }\end{array}$} & .028 & .044 & .059 & .058 & .044 \\
\hline \multicolumn{2}{|c|}{ Median } & $1.53^{\mathrm{a}}$ & $2.80^{\mathrm{a}}$ & $2.75^{\mathrm{a}}$ & $2.76^{a}$ & $2.80^{\mathrm{a}}$ \\
\hline \multicolumn{2}{|c|}{ Mode } & 2 & 3 & 2 & 2 & 3 \\
\hline \multicolumn{2}{|c|}{$\begin{array}{l}\text { Std. } \\
\text { Deviatio } \\
\text { n }\end{array}$} & .500 & .780 & $\begin{array}{r}1.03 \\
0\end{array}$ & $\begin{array}{r}1.02 \\
6\end{array}$ & .780 \\
\hline \multicolumn{2}{|c|}{ Variance } & .250 & .609 & $\begin{array}{r}1.06 \\
1\end{array}$ & $\begin{array}{r}1.05 \\
3\end{array}$ & .609 \\
\hline \multicolumn{2}{|c|}{$\begin{array}{l}\text { Skewnes } \\
\text { s }\end{array}$} & -.117 & -.244 & -.095 & -.091 & -.244 \\
\hline \multicolumn{2}{|c|}{$\begin{array}{l}\text { Std. } \\
\text { Error of } \\
\text { Skewnes } \\
\text { S }\end{array}$} & .138 & .138 & .138 & .138 & .138 \\
\hline \multicolumn{2}{|c|}{ Kurtosis } & $\begin{array}{r}- \\
1.99 \\
9\end{array}$ & -.318 & $\begin{array}{r}- \\
1.26 \\
9\end{array}$ & $\begin{array}{r}- \\
1.26 \\
8\end{array}$ & -.318 \\
\hline \multicolumn{2}{|c|}{$\begin{array}{l}\text { Std. } \\
\text { Error of } \\
\text { Kurtosis }\end{array}$} & .276 & .276 & .276 & .276 & .276 \\
\hline \multirow{3}{*}{$\begin{array}{l}\text { Per } \\
\text { cent } \\
\text { iles }\end{array}$} & 25 & $1.03^{b}$ & $2.16^{\mathrm{b}}$ & $1.84^{\mathrm{b}}$ & $1.85^{\mathrm{b}}$ & $2.16^{\mathrm{b}}$ \\
\hline & 50 & 1.53 & 2.80 & 2.75 & 2.76 & 2.80 \\
\hline & 75 & & 3.51 & 3.67 & 3.67 & 3.51 \\
\hline
\end{tabular}

a. Calculated from grouped data.

b. Percentiles are calculated from grouped data. 
Std.

\begin{tabular}{lc|r|c} 
& Mean & Deviation & $\mathrm{N}$ \\
\hline $\begin{array}{l}\text { Sustainable } \\
\text { Business strategies }\end{array}$ & 19.45 & 2.321 & 310 \\
\hline Quality Treatment & 19.45 & 2.321 & 310 \\
\hline $\begin{array}{l}\text { Knowledge } \\
\text { Information }\end{array}$ & 19.18 & 3.083 & 310 \\
\hline Human Capital & 19.18 & 3.083 & 310 \\
\hline $\begin{array}{l}\text { Transformational } \\
\text { Leadership and }\end{array}$ & 19.73 & 2.098 & 310 \\
$\begin{array}{l}\text { Financial } \\
\text { Management }\end{array}$ & & & \\
\hline
\end{tabular}

Reliability Statistics See table 3.

Cronbach's

Alpha Based on

Cronbach's Standardized

\begin{tabular}{|c|c|c|}
\hline Alpha & Items & $\mathrm{N}$ of Items \\
\hline .953 & .961 & 30 \\
\hline
\end{tabular}

Descriptive Statistics See table 6.

Std.

\begin{tabular}{lr|r|r} 
& Mean & Deviation & \multicolumn{1}{l}{ N } \\
\hline $\begin{array}{l}\text { Sustainable } \\
\text { Business strategies }\end{array}$ & 19.45 & 2.321 & 310 \\
\hline $\begin{array}{l}\text { Quality Treatment } \\
\text { Knowledge }\end{array}$ & 19.45 & 2.321 & 310 \\
\hline $\begin{array}{l}\text { Information } \\
\text { Human Capital }\end{array}$ & 19.18 & 3.083 & 310 \\
\hline $\begin{array}{l}\text { Transformational } \\
\text { Leadership and } \\
\text { Financial } \\
\text { Management }\end{array}$ & 19.73 & 2.098 & 310 \\
\hline
\end{tabular}

Correlations See table 5.

Correlation Matrix and Test of Significance

Table: Correlation Matrix with Test of Significance

\begin{tabular}{|c|c|c|c|c|c|c|}
\hline & & S & ent & tion & ital & t \\
\hline $\begin{array}{l}\text { Sustaina } \\
\text { ble } \\
\text { Business } \\
\text { strategie }\end{array}$ & $\begin{array}{l}\text { Pearso } \\
\mathrm{n} \\
\text { Correl } \\
\text { ation }\end{array}$ & 1 & $\begin{array}{c}1.00 \\
0^{* *}\end{array}$ & $\begin{array}{r}.931 \\
* * *\end{array}$ & $\begin{array}{r}.931 \\
* *\end{array}$ & .844 \\
\hline \multirow[t]{2}{*}{$\mathrm{s}$} & $\begin{array}{l}\text { Sig. } \\
(2- \\
\text { tailed) }\end{array}$ & & .000 & .000 & .000 & .000 \\
\hline & $\mathrm{N}$ & 310 & 310 & 310 & 310 & 310 \\
\hline \multirow[t]{3}{*}{$\begin{array}{l}\text { Quality } \\
\text { Treatme } \\
\text { nt }\end{array}$} & $\begin{array}{l}\text { Pearso } \\
\mathrm{n} \\
\text { Correl } \\
\text { ation }\end{array}$ & $\begin{array}{r}1.00 \\
0^{* *}\end{array}$ & 1 & $\begin{array}{r}.931 \\
* * *\end{array}$ & .931 & .844 \\
\hline & $\begin{array}{l}\text { Sig. } \\
(2- \\
\text { tailed) }\end{array}$ & .000 & & .000 & .000 & .000 \\
\hline & $\mathrm{N}$ & 310 & 310 & 310 & 310 & 310 \\
\hline \multirow[t]{3}{*}{$\begin{array}{l}\text { Knowle } \\
\text { dge } \\
\text { Informat } \\
\text { ion }\end{array}$} & $\begin{array}{l}\text { Pearso } \\
\mathrm{n} \\
\text { Correl } \\
\text { ation }\end{array}$ & $\begin{array}{r}931 \\
* * *\end{array}$ & .931 & 1 & $\begin{array}{c}1.00 \\
0^{* * *}\end{array}$ & .591 \\
\hline & $\begin{array}{l}\text { Sig. } \\
(2- \\
\text { tailed) }\end{array}$ & .000 & .000 & & .000 & .000 \\
\hline & $\mathrm{N}$ & 310 & 310 & 310 & 310 & 310 \\
\hline \multirow[t]{3}{*}{$\begin{array}{l}\text { Human } \\
\text { Capital }\end{array}$} & $\begin{array}{l}\text { Pearso } \\
\mathrm{n} \\
\text { Correl } \\
\text { ation }\end{array}$ & .931 & .931 & $\begin{array}{r}1.00 \\
0^{* * *}\end{array}$ & 1 & .591 \\
\hline & $\begin{array}{l}\text { Sig. } \\
(2- \\
\text { tailed })\end{array}$ & .000 & .000 & .000 & & .000 \\
\hline & $\mathrm{N}$ & 310 & 310 & 310 & 310 & 310 \\
\hline
\end{tabular}


Volume 9 Issue 9 September 2021

\begin{tabular}{|c|c|c|c|c|c|c|}
\hline $\begin{array}{l}\text { Transfor } \\
\text { mational } \\
\text { Leaders } \\
\text { hip and }\end{array}$ & $\begin{array}{l}\text { Pearso } \\
\mathrm{n} \\
\text { Correl } \\
\text { ation }\end{array}$ & $\begin{array}{r}.844 \\
* *\end{array}$ & $\begin{array}{r}844 \\
* *\end{array}$ & $\begin{array}{r}.591 \\
* *\end{array}$ & $\begin{array}{r}.591 \\
* *\end{array}$ & 1 \\
\hline $\begin{array}{l}\text { Financia } \\
1 \\
\text { Manage }\end{array}$ & $\begin{array}{l}\text { Sig. } \\
(2- \\
\text { tailed) }\end{array}$ & .000 & .000 & .000 & .000 & \\
\hline ment & $\mathrm{N}$ & 310 & 310 & 310 & 310 & 310 \\
\hline
\end{tabular}

**. Correlation is significant at the 0.01 level (2tailed).

\section{Correlations see table 7}

\begin{tabular}{|c|c|c|c|c|c|c|}
\hline & & $\begin{array}{c}\text { Susta } \\
\text { inabl } \\
\text { e } \\
\text { Busin } \\
\text { ess } \\
\text { strate } \\
\text { gies }\end{array}$ & $\begin{array}{l}\text { Quali } \\
\text { ty } \\
\text { Treat } \\
\text { ment }\end{array}$ & $\begin{array}{c}\text { Kno } \\
\text { wled } \\
\text { ge } \\
\text { Infor } \\
\text { matio } \\
\text { n }\end{array}$ & $\begin{array}{c}\text { Hum } \\
\text { an } \\
\text { Capit } \\
\text { al }\end{array}$ & $\begin{array}{c}\text { Trans } \\
\text { form } \\
\text { ation } \\
\text { al } \\
\text { Lead } \\
\text { ershi } \\
\text { p and } \\
\text { Finan } \\
\text { cial } \\
\text { Mana } \\
\text { geme } \\
\text { nt }\end{array}$ \\
\hline \multirow[t]{5}{*}{$\begin{array}{l}\text { Pearson } \\
\text { Correlat } \\
\text { ion }\end{array}$} & $\begin{array}{l}\text { Sustainabl } \\
\text { e Business } \\
\text { strategies }\end{array}$ & 1.000 & 1.000 & .931 & .931 & .844 \\
\hline & $\begin{array}{l}\text { Quality } \\
\text { Treatment }\end{array}$ & 1.000 & 1.000 & .931 & .931 & .844 \\
\hline & $\begin{array}{l}\text { Knowledg } \\
\text { e } \\
\text { Informatio } \\
n\end{array}$ & .931 & .931 & 1.000 & 1.000 & .591 \\
\hline & $\begin{array}{l}\text { Human } \\
\text { Capital }\end{array}$ & .931 & .931 & 1.000 & 1.000 & .591 \\
\hline & $\begin{array}{l}\text { Transform } \\
\text { ational } \\
\text { Leadershi } \\
\text { p and } \\
\text { Financial } \\
\text { Managem } \\
\text { ent }\end{array}$ & .844 & .844 & .591 & .591 & 1.000 \\
\hline \multirow[t]{2}{*}{$\begin{array}{l}\text { Sig. (1- } \\
\text { tailed) }\end{array}$} & $\begin{array}{l}\text { Sustainabl } \\
\text { e Business } \\
\text { strategies }\end{array}$ & • & .000 & .000 & .000 & .000 \\
\hline & $\begin{array}{l}\text { Quality } \\
\text { Treatment }\end{array}$ & .000 & & .000 & .000 & .000 \\
\hline
\end{tabular}

\begin{tabular}{|c|c|c|c|c|c|}
\hline $\begin{array}{l}\text { Knowledg } \\
\mathrm{e} \\
\text { Informatio } \\
\mathrm{n}\end{array}$ & .000 & .000 & & .000 & .000 \\
\hline $\begin{array}{l}\text { Human } \\
\text { Capital }\end{array}$ & .000 & .000 & .000 & & .000 \\
\hline $\begin{array}{l}\text { Transform } \\
\text { ational } \\
\text { Leadershi } \\
\text { p and } \\
\text { Financial } \\
\text { Managem } \\
\text { ent }\end{array}$ & .000 & .000 & .000 & .000 & \\
\hline $\begin{array}{l}\text { Sustainabl } \\
\text { e Business } \\
\text { strategies }\end{array}$ & 310 & 310 & 310 & 310 & 310 \\
\hline $\begin{array}{l}\text { Quality } \\
\text { Treatment }\end{array}$ & 310 & 310 & 310 & 310 & 310 \\
\hline $\begin{array}{l}\text { Knowledg } \\
\text { e } \\
\text { Informatio } \\
\text { n }\end{array}$ & 310 & 310 & 310 & 310 & 310 \\
\hline $\begin{array}{l}\text { Human } \\
\text { Capital }\end{array}$ & 310 & 310 & 310 & 310 & 310 \\
\hline $\begin{array}{l}\text { Transform } \\
\text { ational } \\
\text { Leadershi } \\
\text { p and } \\
\text { Financial } \\
\text { Managem } \\
\text { ent }\end{array}$ & 310 & 310 & 310 & 310 & 310 \\
\hline
\end{tabular}

ANOVA ${ }^{\text {a }}$ see table 9.

\begin{tabular}{llr|r|r|r|r}
\multicolumn{1}{l}{} & $\begin{array}{c}\text { Sum of } \\
\text { Model }\end{array}$ & Squares & df & $\begin{array}{c}\text { Mean } \\
\text { Square }\end{array}$ & F & Sig. \\
\hline $\begin{array}{l}\text { Regres } \\
\text { sion }\end{array}$ & 1664.77 & 2 & 832.387 & 4533131 & $.000^{\mathrm{b}}$ \\
\hline $\begin{array}{l}\text { Residu } \\
\text { al }\end{array}$ & .000 & 307 & .000 & & \\
\hline Total & 1664.77 & 309 & & & \\
& 4 & & & & \\
\hline
\end{tabular}

a. Dependent Variable: Sustainable Business strategies

b. Predictors: (Constant), Transformational Leadership and Financial Management, Human Capital

Model Summary see table 10.

\begin{tabular}{ll|l|l|l} 
M & R & R & Adj & Std.
\end{tabular} 
ISSN-2347-9698

Volume 9 Issue 9 September 2021

\begin{tabular}{|c|c|c|c|c|c|c|c|c|}
\hline $\begin{array}{l}\text { o } \\
\text { d } \\
\text { el }\end{array}$ & $\begin{array}{l}\mathrm{Sq} \\
\text { ua } \\
\text { re }\end{array}$ & $\begin{array}{l}\text { uste } \\
\mathrm{d} R \\
\text { Squ } \\
\text { are }\end{array}$ & $\begin{array}{l}\text { Erro } \\
\mathrm{r} \text { of } \\
\text { the } \\
\text { Esti } \\
\text { mate }\end{array}$ & $\begin{array}{c}\mathrm{R} \\
\text { Squ } \\
\text { are } \\
\text { Cha } \\
\text { nge }\end{array}$ & $\begin{array}{c}\text { F } \\
\text { Cha } \\
\text { nge }\end{array}$ & $\begin{array}{c}\mathrm{df} \\
1\end{array}$ & $\begin{array}{c}\text { df } \\
2\end{array}$ & $\begin{array}{c}\text { Sig. } \\
\text { F } \\
\text { Cha } \\
\text { nge }\end{array}$ \\
\hline $\begin{array}{cc}1 . \\
\\
& 00 \\
& 0^{\mathrm{a}}\end{array}$ & $\begin{array}{r}1.0 \\
00\end{array}$ & $\begin{array}{r}1.00 \\
0\end{array}$ & .000 & $\begin{array}{r}1.00 \\
0\end{array}$ & $\begin{array}{r}460 \\
868 \\
361 \\
867 \\
579 \\
20.0 \\
00\end{array}$ & 2 & $\begin{array}{r}30 \\
7\end{array}$ & .000 \\
\hline
\end{tabular}

a. Predictors: (Constant), Transformational

Leadership and Financial Management , Human Capital

Model Summary ${ }^{\mathbf{b}}$ See table 8 .

\begin{tabular}{|c|c|c|c|c|c|c|c|c|}
\hline \multirow[b]{3}{*}{ M } & \multirow[b]{3}{*}{$\mathrm{R}$} & \multirow[b]{2}{*}{ Adj } & \multirow{2}{*}{$\begin{array}{c}\text { Std. } \\
\text { Erro } \\
\mathrm{r} \text { of }\end{array}$} & \multicolumn{5}{|c|}{ Change Statistics } \\
\hline & & & & $\mathrm{R}$ & & & & \\
\hline & & uste & the & $\mathrm{Squ}$ & & & & Sig. \\
\hline o & $\mathrm{Sq}$ & d R & Esti & are & $\mathrm{F}$ & & & $\mathrm{F}$ \\
\hline $\mathrm{d}$ & ua & $\mathrm{Squ}$ & mat & Cha & Cha & df & df & Cha \\
\hline el $R$ & re & are & $\mathrm{e}$ & nge & nge & 1 & 2 & nge \\
\hline
\end{tabular}

The above table is the outputs for the model's overall significance; the F-statistic is 97.728 with a corresponding p-value 0.000 . This indicates that there is strong evidence of an existing linear

\section{FINDINGS AND DISCUSSION}

Health care set ups have significant positive linear relationship with predicted variables with sustainable business strategies $(=0.931)$ and corresponding p-value 0.000 at $1 \%$ level of significance. Correspond to these results our first hypothesis "H1 Quality treatment will have positive significant impact on sustainable business strategies in private health care set ups.

that $59.1 \%$ of the variation in the Volatility Uncertainty is due to its linear relationship with the predictors. The newly added variable Knowledge Sharing has a positively impact on the Volatility Uncertainty. Furthermore, the variable has significant relationship as per the p-value 0.000 . With the inclusion of the moderator variable the significance of the other predictors has improved. But now its significance is at boarded line with $\mathrm{p}$ value 0.079 . Table 5 presents the Pearson's

\begin{tabular}{rr|r|r|r|r|r|r|r|r|r|r}
\hline 1 & 1. & 1. & 1.00 & .000 & 1.00 & 460 & 2 & 30 & .000 & .135 \\
& 00 & 00 & 0 & & 0 & 868 & & 7 & & \\
& 0 & 0 & & & & 361 & & & & \\
& & & & & 867 & & & & \\
& & & & & & 579 & & & & \\
& & & & & & & & \\
& & & & & 20.0 & & & & \\
& & & & & 00 & & & & \\
\hline
\end{tabular}

a. Predictors: (Constant), Transformational Leadership and Financial Management, Human Capital

b. Dependent Variable: Sustainable Business strategies

Above table presents the co-efficient of fitted regression model with test of their individual significance. All the predictors has shown positive relationship with sustainable business strategies to Quality treatment, Knowledge Information, Human Capitals, and Transformational leadership and financial management skills has insignificant relationship having $\mathrm{p}$-value 0.365 .

\section{A $C$}

relationship between the dependent variable sustainable business strategies of its predictors.

The sum of squares of the regression has improved with the inclusion of moderator variable and the overall significance of the model is sustained.

Is established. H2 Knowledge Implementation will have positive significant impact on sustainable business strategies in private health care set ups.

The regression model with sustainable business strategies as dependent variable and with predictors: Knowledge Implementation,Human Capital, Transformational leadership and financial management skills is fitted. The co-efficient of determination is 0.591 which means

correlation co-efficient along with the test of significance of positive correlation (one tailed test). With the inclusion of moderator variable transformational leadership that increased to 0.931 from the previous 0.841 .

\section{LIMITATION AND FUTURE RESEARCH}


This research was conducted only in the urban city of Lahore, Pakistan. Some remote areas of Basic health Units and District Head Quarters could be extended to cover more population and similarly some more variables can be studied such as moral behavior, training \& development and competitive nature to interpret wide area to conduct sustainable business strategies of health care set ups . Due to lack of time and resources data collection remained low due to lockdown period of cove 19 during the authorship time of this paper.

\section{Reference}

1. Abdallah, A.B., \& Alkhaldi, R. Z. (2019). Lean bundles in health care: a scoping review. Journal of Health Organization and Management, 33(4), 488-510.

5. Healthcare, 2010105818758088.

6. Bass, B. M. (1985). Leadership and performance beyond expectations. New York, Free Press.

7. Bass, B. M., \& Avolio, B. J. (1994). Transformational leadership and organizational culture. The International Journal of Public Administration, 17(3-4), 541-554.

8. Cossette B, Bergeron J, Ricard G, Éthier JF, Joly-Mischlich T, Levine M, Sene M, Mallet L, Lanthier L, Payette $\mathrm{H}$. Knowledge translation strategy to reduce the use of potentially inappropriate medications in hospitalized elderly adults. J Am Geriatr Soc. 2016;64:2487-94.

9. Ellen ME, Lavis JN, Shemer J. Examining the use of health systems and policy research in the health policymaking process in Israel: views of researchers. Health Res Policy Syst. 2016;14(1):66.

10. Gadit AAM. Opinion and debate- corruption in medical practice: how far have we gone? JPMA - Journal of the Pakistan Medical Association. 2011;61(1):93.

11. Graham ID, Kothari A, McCutcheon C. Moving knowledge into action for more effective practice, programmes and policy: protocol for a research programme on integrated knowledge translation. Implement Sci. 2018;13:22.

12. Harvey G, Kitson A. PARIHS revisited: from heuristic to integrated framework for the successful implementation of
2. Abdallah, A.B., Dahiyat, S.E., \& Matsui, Y. (2019). Lean management and innovation performance: Evidence from international manufacturing companies. Management Research Review, 42(2), 239262.

3. Banja JD, Eisen A. Ethical perspectives on knowledge translation in rehabilitation. Arch Phys Med Rehabil. 2013;94:S55-60.

4. Bahadori, M., Teymourzadeh, E., Faizy Bagejan, F., Ravangard, R., Raadabadi, M., \& Hosseini, S. M. (2018). Factors affecting the effectiveness of quality control circles in a hospital using a combination of fuzzy VIKOR and grey relational analysis Proceedings of Singapore knowledge into practice. Implement Sci. 2015;11:33.

13. Hater, J. J., \& Bass, B. M. (1988). Superiors' evaluations and subordinates' perceptions of transformational and transactional leadership. Journal of Applied Psychology, 73(4), 695.

14. Howell, J. M., \& Avolio, B. J. (1993). Transformational leadership, transactional leadership, locus of control, and support for innovation: Key predictors of consolidated-business-unit performance. Journal of Applied Psychology, 78(6), 891.

15. Irfan SM, Ijaz A. Comparison of service quality between private and public hospitals: empirical evidences from Pakistan.Journal of Quality and Technology Management. 2011;7(1):1- 22.

16. Ismail, A. M., Reza, R., \& Mahdi, S. (2012). Analysis the relationship between cultural intelligence and transformational leadership. International Journal of Business and Social Science, 3(14), 252261.

17. Javed SA, Ilyas F. Service quality and satisfaction in healthcare sector of Pakistan - the patients' expectations. Int J Health Care Qual Assur. 2018;31(6):489- 501.

18. Kang, M., and Lee, M. J. (2017), "Absorptive capacity, knowledge sharing, and innovative behaviour of R\&D employees". Technology Analysis \& 
Strategic Management, Vol.29 No.2, pp.219-232. *Kang, Y. J.,

19. Kim, S. E., and Chang, G. W. (2008), "The impact of knowledge sharing on work performance: An empirical analysis of the public employees' perceptions in South Korea".

20. Kim, S. L., and Yun, S. (2015), "The effect of co-worker knowledge sharing on performance and its boundary conditions: An interactional perspective". Journal of AppliedPsychology, Vol.100 No.2, pp.575.

21. Parasuraman A, Zeithaml VA, Berry LL. A conceptual model of service quality and its implications for future research. the Journal of Marketing. 1985;41- 50.

22. Purcărea VL, Gheorghe IR, Petrescu CM. The assessment of perceived service quality of public health care services in Romania using the SERVQUAL scale. Procedia Economics and Finance. 2013;6:573- 585.

23. Pramanik A. Patients' perception of service quality of health care services in India: a comparative study on urban andrural hospitals. Journal of Health Management. 2016;18(2):1- 13.

24. Patrick DL, Chiang YP. Measurement of health outcomes in treatment effectiveness evaluations: conceptual and methodological challenges. Med Care. 2000;38(9):II14- II25.

25. Patrick DL, Chiang YP. Measurement of health outcomes in treatment effectiveness evaluations: conceptual and methodological challenges. Med Care. 2000;38(9):II14- II25.

26. Rezaei J, Kothadiya O, Tavasszy L, Kroesen M. Quality assessment of airline baggage handling systems using SERVQUALand BWM. Tour Manag. 2018;66:85- 93.

27. Rosenbaum SE, Glenton C, Wiysonge CS, Abalos E, Mignini L, Young T, Althabe F, Ciapponi A, Marti SG, Meng Q. Evidence summaries tailored to health policymakers in low-and middle-income countries. Bull World Health Organ. 2011;89:54-61.
28. Saks, A. M., \& Burke- Smalley, L. A. (2014). Is transfer of training related to firm performance? International Journal of Training and Development, 18(2), 104115.

29. Solomon, R. T. (2019). Strategies for Human Resources Professionals Using Social Networking Websites for Hiring Decisions.

30. Siddiqi S, Shennawy A, Mirza Z, Drager N, Sabri B. Assessing trade in health services in countries of the Eastern Mediterranean from a public health perspective. Int J Health Plann Manage. 2010;25(3):231- 250.

31. Shabbir A, Malik SA, Malik SA. Measuring patients' healthcare service quality perceptions, satisfaction, and loyalty inpublic and private sector hospitals in Pakistan. International Journal of Quality \& Reliability Management. 2016;33(5):538- 557.

32. Shafiq M, Naeem MA, Munawar Z, Fatima I. Service quality assessment of hospitals in Asian context: an empirical evidence from Pakistan. INQUIRY: The Journal of Health Care Organization, Provision, and Financing. 2017;54:0046958017714664.Intl Journal of Public Administration, Vol.31 No.14, pp.1548-1568. 